\title{
МОРФОЛОГИЧЕСКИЕ ПОКАЗАТЕЛИ ТУШ И КОСТЕЙ ПО ОТДЕЛАМ СКЕЛЕТА У БЫЧКОВ АНТИЛОПЫ КАННА
}

\author{
V. E. Nikitchenko, D. V. Nikitchenko, E. O. Rystsova, \\ K. M. Kondrashkina, S. O. Panakhova
}

\section{MORPHOLOGICAL CHARACTERISTICS OF THE CARCASSES AND BONES OF DIFFERENT DEPARTMENTS OF THE SKELETON OF BULL-CALVES OF THE ANTELOPE OF CANNES}

\begin{abstract}
Никитченко Владимир Ефимович - д-р ветеринар. наук, проф. департамента ветеринарной медицины Аграрно-технологического института Российского университета дружбы народов, г. Москва. E-mail: nikitchenko-ve@rudn.ru

Никитченко Дмитрий Владимирович - д-р биол. наук, доц. департамента ветеринарной медицины Аграрно-технологического института Российского университета дружбы народов, г. Москва. E-mail: nikitchenko-dv@rudn.ru

Рысцова Екатерина Олеговна - канд. с.-х. наук, доц. департамента ветеринарной медицины Аграрно-технологического института Российского университета дружбы народов, г. Москва.

E-mail: rystsova-eo@rudn.ru
\end{abstract}

Кондрашкина Ксения Максимовна - студ. 4-го курса Аграрно-технологического института Российского университета дружбы народов, г. Москва. E-mail: 1032161257@rudn.ru

Панахова Сабина Октаевна - студ. 3-го курса Аграрно-технологического института Российского университета дружбы народов, г. Москва. E-mail: 1032176069@rudn.ru

Цель исследования - изучение морфологических показателей туш и костей антилопы канна. Исследование морфологического состава и особенностей формирования скелета бьчков антилоп канна проводили в заповеднике Аскания-Нова. Контрольный убой животных произведен в возрасте 6 и 60 месяцев. По сравнению с 6-месячными у 60-месячных бычков абсолютная масса туш увеличивается в 3,75 раза, мышечной ткани - в 4,01 раза, жировой - в 7,30 раза, костной - в 2,79 раза. Относительная масса мышечной ткани у взрослых бычков повышается на 4,66 \%, жировой ткани - на 0,95 \%, в то время как костной ткани уменьшается на 5,47\%. Абсолютная масса костей осе-
Nikitchenko Vladimir Efimovich - Dr. Veterinary Sci., Prof., Department of Veterinary Medicine, Agrarian and Technological Institute, Peoples' Friendship University of Russia, Moscow.

E-mail: nikitchenko-ve@rudn.ru

Nikitchenko Dmitry Vladimirovich - Dr. Biol. Sci., Assoc. Prof., Department of Veterinary Medicine, Agrarian and Technological Institute, Peoples' Friendship University of Russia, Moscow.

E-mail: nikitchenko-dv@rudn.ru

Rystsova Ekaterina Olegovna - Cand. Agr. Sci Assoc. Prof., Department of Veterinary Medicine, Agrarian and Technological Institute, Peoples' Friendship University of Russia, Moscow.

E-mail: rystsova-eo@rudn.ru

Kondrashkina Ksenia Maximovna - 4-Year Student, Agrarian and Technological Institute, Peoples' Friendship University of Russia, Moscow.

E-mail: 1032161257@rudn.ru

Panakhova Sabina Oktaevna - 3-Year Student, Agrarian and Technological Institute, Peoples' Friendship University of Russia, Moscow.

E-mail:1032176069@rudn.ru

вого скелета с возрастом увеличивается в 3,02 раза, в то время как относительная масса повышается на 3,67 \%; костей перифрерического скелета - в 2,61 раз, но уменьшается соответственно на 3,66 \%. Наибольшую массу в возрасте как 60, так и 6 месяцев в осевом скелете занимают ребра и грудные позвонки, абсолютная масса которых составила 3152 и 2565 г, относительная - 16,06 и 13,07 \%, а в периферическом отделе - бедренная и плечевая, масса которых составила 1918 и 1798 г, или 9,77 и 9,16 \% соответственно. У 60месячных бьчков содержание белка и жира в длиннейшей мышие спины увеличилось на 0,57 и 0,71 \%, в полуперепончатой - на 0,73 и 0,59\% 
соответственно, в то время как содержание воды уменьшилось на 1,14 и 1,33 \%.

Ключевые слова: антилопа, скелет, костная ткань, жировая ткань, туша, морфологический состав.

The research objective was studying morphologi$\mathrm{cal}$ indicators of hulks and bones of the antelope of Cannes. The research of morphological structure and features of formation of a skeleton of bull-calves of antelopes of Cannes was carried out in the reserve Askaniya-Nova. The control slaughter of animals was made at the age of 6 and 60 months. In comparison with 6-month-old at 60-month-old bullcalves the absolute mass of the hulks increased by 3.75 times, muscular tissue - by 4.01 times, fatty by 7.30 times, bone - by 2.79 times. The relative mass of muscular tissue in adult bull-calves increased by $4.66 \%$, fatty tissue - for $0.95 \%$ while a bone tissue decreases by $5.47 \%$. The absolute mass of the bones of an axial skeleton increased with age by 3.02 times while relative weight increased by $3.67 \%$; the bones of peripheral skeleton - by 2.61 times, but the decreases made $3.66 \%$ respectively. The greatest weight aged both 60 , and 6 months in an axial skeleton occupied the edges and chest vertebras which absolute weight made 3152 and $2565 \mathrm{~g}$, relative - 16.06 and $13.07 \%$, and in peripheral department - femoral and humeral, which weight made 1918 and 1798, or 9.77 and $9.16 \%$, respectively. At 60-month-old bull-calves protein content and fat in the longest e muscle latissimus dorsi increased by 0.57 and $0.71 \%$, in semi-membranous - by 0.73 and $0.59 \%$, respectively; the content of water decreased by 1.14 and $1.33 \%$.

Keywords: antelope, skeleton, bone tissue, fat tissue, carcass, morphological composition.

Введение. Антилопа канна (Taurotragus oryx) - одна из крупнейших африканских антилоп, хорошо поддающаяся одомашниванию и имеющая огромный фермерский потенциал для производства мяса [1]. Преимущество для сельского хозяйства заключается в том, что антилопа канна может населять среды, непригодные для домашних животных, такие как районы, слишком засушливые для обычного домашнего скота, горные районы, районы с тундровой или таежной растительностью. Также антилопа канна, как и другие дикие жвачные животные, имеет морфологические приспособления, позволяющие ей питаться грубым кормом. Эта адап- тация делает антилопу более эфффективной в использовании кормов в сравнении с одомашненными жвачными $[2,5]$. Благодаря своим выдающимся качествам, антилопа канна была рекомендована FAO как вид, пригодный для одомашнивания (Scherf, 2000).

В странах Южной и Восточной Афррики антилоп канна исторически успешно выращивают для получения мясной продукции. С 2002 г. антилоп канна разводят под управлением Чешского университета естественных наук в Праге [2]. Доместикация канн была проведена на Украине в Аскания-Нова, куда в 1892 г. было завезено первое стадо афрриканских жвачных [3]. При этом в настоящий момент имеется недостаточное количество публикаций, описывающих постнатальное развитие антилоп как по мышцам, так и по костям. Изучение роста, развития и морфологических особенностей антилопы канна поможет повлиять на формирование мясной продуктивности данного вида животных.

Ученые отмечают, что качество мяса во многом определено степенью развития мышечной и костной тканей $[3,6]$. Мясная продуктивность определяется не только выходом мякотной части туши, но и относительным содержанием мышечной ткани к жировой и костной. Установлено, что повышение убойного выхода антилопы канна с возрастом увеличивалось в большей степени за счет интенсивного роста мышечной массы, в меньшей степени - за счет роста костей скелета. Однако в формировании общих размеров, конституционного типа и экстерьера главная роль принадлежит скелету. В ходе онтогенеза размеры животного увеличиваются в пределах, строго обусловленных генетической программой. Рост скелета определяет высоту в холке, длину и ширину животного. Так как характеристика телосложения, тесно связанная с продуктивностью животного, основывается на морфологических показателях осевого скелета и периферического, для изучения роста и развития антилопы канна необходимо изучить особенности формирования скелета.

Цель исследования: изучение морфологических показателей туш и костей антилопы канна.

Материалы и методы исследования. Особенности формирования скелета изучали у антилоп канна, выращенных в заповеднике Аскания-Нова. Контрольный убой бычков проводили в возрасте 6 и 60 месяцев, живая масса которых составила 139,5 и 551,6 кг соответственно. Проведена препаровка туш с выделением мышечной, жировой, костной и других тканей. Химиче- 
ский состав определяли в полуперепончатой мышце, двуглавой мышце бедра, длиннейшей мышце спины и двуглавой мышце плеча.

Убой животных проводили на убойной площадке заповедника Аскания-Нова, с предубойной выдержкой животных 24 ч. Голову отчленяли от туши по затылочно-атлантному суставу, нижнюю часть грудных конечностей отделяли между костями запястного сустава и пястной костью, тазовых конечностей - между костями заплюсневого сустава и плюсны. При туше оставляли два первых хвостовых позвонка.

Массу шейных, грудных, поясничных и двух хвостовых позвонков, крестцовой и грудной костей делили на два и прибавляли массу костей грудной и тазовой конечностей и ребер. Поэтому в таблицах 1, 2 приведена масса мышечной, жировой и костной тканей полутуши.

Полутуши препарировали с учетом анатомического пособия [4].

Результаты исследования и их обсуждение. По данным таблицы 1, 60-месячные бычки превосходят 6-месячных по живой массе в 3,95 раза, отношение масс полутуш составляет 3,77 . Однако не все ткани развиваются изометрично. Больше всего в туше содержится мышечной ткани: у 6-месячных - 76,12 \%, у 60-месячных на $4,66 \%$ больше.

Кости скелета, наоборот, в раннем возрасте имеют относительную массу больше на 5,47 \%, чем в зрелом. Это объясняется тем, что для обеспечения фуннкциональной деятельности организма скелет в эмбриональном периоде растет интенсивнее, чем мышечная ткань, в то время как в постнатальном онтогенезе происходит интенсивнее рост мышечной ткани с последующим снижением после полового созревания. Отношение мышечной ткани к костям у 6месячных бычков составляет $3,64: 1$, у 60 месячных $-5,22$ : 1. Количество жировой ткани в тушах бычков составляет лишь 1,01-1,96 \% от общей массы полутуши, что указывает на ограниченное их кормление.

\section{Морфологический состав полутуш антилоп канны}

Таблица 1

\begin{tabular}{|l|c|c|c|c|}
\hline \multirow{2}{*}{ Maсcа, г } & \multicolumn{4}{|c|}{ Возраст, месс. } \\
\cline { 2 - 5 } & 6 & 60 & 6 & 60 \\
\cline { 2 - 5 } & \multicolumn{2}{|c|}{ Абсолютная масса, } & $\begin{array}{c}\text { Относительная масса, } \\
\% \text { к массе полутуши }\end{array}$ \\
\hline Возраст, мес. & 6 мес & 60 & 6 & 60 \\
\hline Живая масса & $139500 \pm 2,3$ & $551600 \pm 6,5$ & - & - \\
\hline Масса полутуши & $33570 \pm 680$ & $126870 \pm 2715$ & 100 & 80,78 \\
\hline Масса мышечной ткани & $25555 \pm 467$ & $102488 \pm 2319$ & 76,12 & 1,96 \\
\hline Масса жировой ткани & $340 \pm 15$ & $2482 \pm 80$ & 1,01 & 1,79 \\
\hline Масса других тканей & $645 \pm 36$ & $2275 \pm 74$ & 1,92 & 15,47 \\
\hline Масса костей & $7030 \pm 153$ & $19625 \pm 419$ & 20,94 & \\
\hline
\end{tabular}

Скорость роста костей по анатомическим отделам скелета различна. Согласно данным таблицы 2, кратность увеличения абсолютной массы костей осевого скелета составляет 3,02 раза, периферического отдела - 2,61. У 6-месячных бычков относительная масса перифрерического отдела скелета превышает осевой на 11,18\%, у 60-месячных - на 3,85 \%. Относительная масса осевого скелета увеличивается на 3,61 \%, периферического - уменьшается на 3,66 \%.

Из всех костей туловища и шеи наибольший прирост абсолютной массы наблюдается у ребер и у грудной кости, за счет которого относительная масса осевого скелета с возрастом увеличивается на 6,13 и 0,49\% соответственно, в то время как относительная масса шейных, грудных, поясничных, крестцовых позвонков и крестцовой кости снижается на 0,$35 ; 0,87 ; 0,9 ; 0,11$ и $0,73 \%$ соответственно. Наибольшую относительную массу в скелете $(16,06 \%)$ занимают ребра вследствие развития и увеличения объема внутренних органов. Кратность увеличения абсолютной массы ребер составляет 4,52 раза, а грудной кости - 3,47. 
Второй по скорости роста - отдел грудной конечности, абсолютная масса которого с возрастом бычков увеличилась в 3,06 раз, а относительная - на 2,02 \%. Наиболее значительный рост в этом отделе отмечен у лопатки. По сравнению с 6-месячными бычками кратность увеличения абсолютной массы лопатки составила 4,76 раз, а относительной $-1,71$. Такой интенсивный рост связан с фуннцциональной нагрузкой на кость. Относительная масса плечевой кости существенно не изменилась, увеличившись лишь на $0,71 \%$, в то время как относительная масса костей предплечья и запястья у 60-месячных бычков в сумме снизилась на 1,25 \% по сравнению с 6-месячными.

В отделе тазовой конечности после 6 месяцев наблюдается замедленная скорость роста. Несмотря на то, что абсолютная масса костей тазовой конечности бычков превосходит абсолютную массу костей грудной конечности в 1,22 раза, их относительная масса снизилась на 5,68 \%. Это объясняется тем, что кости тазовой конечности соединяются с осевым отделом скелета через связки, в то время как грудная конечность соединяется с туловищем мышцами плечевого пояса, прикрепленными к лопатке. Рост лопатки прямо пропорционален интенсивному развитию мышц плечевого пояса, поэтому относительная масса костей грудной конечности в отличие от костей тазовой конечности с возрастом увеличивается. Тазовые кости - единственные в этом отделе, у которых наблюдался положительный прирост относительной массы в 2,54 \%. Относительная масса бедренной кости, костей голени и заплюсны у 60-месячных бычков снизилась на 2,34; 3,11 и 2,79 \% соответственно. Относительная масса костей коленной чашечки с возрастом существенно не изменилась, различие составило $0,05 \%$.

Таблица 2

\section{Абсолютная и относительная масса костей полутуш антилопы канна}

\begin{tabular}{|l|c|c|c|c|}
\hline \multirow{2}{*}{\multicolumn{1}{|c|}{ Название костей }} & \multicolumn{4}{|c|}{ Возраст, мес. } \\
\cline { 2 - 5 } & 6 & 60 & 6 & 60 \\
\cline { 2 - 5 } & \multicolumn{2}{|c|}{ Абсолютная масса, г } & \multicolumn{1}{c|}{ Относительная масса, \% } \\
\hline Общая масса костей полутуши & $7030 \pm 77,3$ & $19625 \pm 186,4$ & 100 & 100 \\
\hline Кости туловища и шеи: & $3122 \pm 43,7$ & $9425 \pm 122,5$ & 44,41 & 48,08 \\
\hline шейные позвонки & $525 \pm 4,7$ & $1397 \pm 25,1$ & 7,47 & 7,12 \\
\hline грудные позвонки & $980 \pm 19,6$ & $2565 \pm 38,0$ & 13,94 & 13,07 \\
\hline поясничные позвонки & $502 \pm 7,8$ & $1225 \pm 10,4$ & 7,14 & 6,24 \\
\hline крестцовая кость & $230 \pm 5,1$ & $498 \pm 8,5$ & 3,27 & 2,54 \\
\hline ребра & $698 \pm 11,2$ & $3152 \pm 47,3$ & 9,93 & 16,06 \\
\hline грудная кость & $142 \pm 3,7$ & $493 \pm 8,4$ & 2,02 & 2,51 \\
\hline хвостовые позвонки & $45 \pm 0,5$ & $105 \pm 1,5$ & 0,64 & 0,53 \\
\hline Грудной конечности: & $1499 \pm 19,8$ & $4580 \pm 44,1$ & 21,32 & 23,34 \\
\hline лопатка & $251 \pm 3,7$ & $1203 \pm 17,9$ & 3,57 & 6,13 \\
\hline плечевая кость & $594 \pm 16,3$ & $1798 \pm 34,8$ & 8,45 & 9,16 \\
\hline кости предплечья & $518 \pm 4,2$ & $1279 \pm 12,4$ & 7,37 & 6,52 \\
\hline кости запястья & $136 \pm 1,2$ & $300 \pm 5,7$ & 1,93 & 1,53 \\
\hline Тазовой конечности: & $2409 \pm 27,94$ & $5610 \pm 58,9$ & 34,27 & 28,59 \\
\hline тазовые кости & $413 \pm 2,3$ & $1652 \pm 21,8$ & 5,87 & 8,41 \\
\hline бедренная кость & $852 \pm 23,7$ & $1918 \pm 37,4$ & 12,11 & 9,77 \\
\hline кости голени & $688 \pm 5,3$ & $1310 \pm 13,8$ & 9,79 & 6,68 \\
\hline кости заплюсны & $394 \pm 3,0$ & $551 \pm 4,6$ & 5,60 & 2,81 \\
\hline коленная чашка & $61 \pm 0,6$ & $179 \pm 1,8$ & 0,86 & 0,91 \\
\hline
\end{tabular}


Для более глубокого изучения качественных показателей мяса провели химическое исследование (табл. 3). Данные химического анализа показали, что у 6-месячных бычков: воды в двуглавой мышце плеча больше, чем в двуглавой мышце бедра, длиннейшей мышце спины и полуперепончатой мышце на 0,68; 0,99 и 0,07 \%; белка меньше - на 0,60; 0,73 и 0,06 \% соответственно. Следовательно, относительное содержание белка наибольшее в длиннейшей мышце спины. Содержание жира у 6-месячных бычков колеблется в пределах 0,83-0,97 \%. С возрастом относительное содержание жира увеличивается: в полуперепончатой мышце - на 0,59 \%; двуглавой мышце бедра - на 0,67; длиннейшей мышце спины - на 0,71 и двуглавой мышце плеча - на 0,52 \%. Повышение относительной массы жира у 60-месячных бычков менее, чем на $1 \%$, свидетельствует об ограниченном кормлении. Содержание золы с возрастом существенно не изменилось, у бычков колеблется в пределах 1,00-1,14 \%.

Таблица 3

\section{Химический состав мышц антилопы канна}

\begin{tabular}{|l|c|c|c|c|}
\hline \multirow{2}{*}{ Показатель } & \multicolumn{4}{|c|}{ Мышца } \\
\cline { 2 - 5 } & $\begin{array}{c}\text { Полупере- } \\
\text { пончатая }\end{array}$ & Двуглавая бедра & $\begin{array}{c}\text { Длиннейшая } \\
\text { спины }\end{array}$ & Двуглавая плеча \\
\hline \multicolumn{5}{|c|}{ 6-месячный бычок } \\
\hline Вода & 76,88 & 76,27 & 75,96 & 76,95 \\
\hline Жир & 0,86 & 0,89 & 0,97 & 0,83 \\
\hline Белок & 21,26 & 21,80 & 21,93 & 1,20 \\
\hline Зола & 1,00 & 1,04 & 1,14 & 75,93 \\
\hline \multicolumn{5}{|c|}{60 -месячный бычок } \\
\hline Вода & 75,55 & 74,77 & 74,82 & 1,35 \\
\hline Жир & 1,45 & 1,56 & 1,68 & 21,70 \\
\hline Белок & 21,99 & 22,62 & 22,50 & 1,02 \\
\hline Зола & 1,01 & 1,05 & 1,00 & \\
\hline
\end{tabular}

\section{Выводы}

1. Живая масса взрослых быков составляет 551,60 кг, а масса туш - 253,74 кг.

2. С возрастом животных содержание мышечной ткани в туше увеличивается на 4,66 \%, жировой - на 0,95\%, в то время как содержание костей снижается на 5,47\%.

3. За период от 6- до 60-месячного возраста бычков абсолютная масса костей осевого отдела скелета увеличилась в 3,02 раза, периферического отдела - в 2,61 раза.

4. Относительная масса грудной конечности увеличилась на 2,02 \%, в то время как костей периферического скелета снижалась на 5,68 \%, так как нагрузка на грудные конечности С возрастом животного повышается.

5. По абсолютной и относительной массе кости скелета 6- и 60-месячных бычков распределены по анатомическим областям туши в следующем убывающем порядке: осевой скелет, тазовая конечность, грудная конечность.

6. С возрастом бычков содержание белка и жира в мышцах увеличилось, в то время как содержание воды уменьшилось.

\section{Литература}

1. Barton L., Bureš D., Kotrba R., Sales J. 2014. Comparison of meat quality between eland (Taurotragus oryx) and cattle (Bos taurus) raised under similar conditions. Meat Science 96:346-352.

2. Kolbabek $P$. Influence of Common Eland (Taurotragus oryx) Meat Composition on its further Technological Processing. Dissertation thesis. Prague, 2018.

3. Никитченко В.Е., Никитченко Д.В., Серегин И.Г. и др. Морфологический состав туш и развитие мышц у антилопы канна // Вест- 
ник РУДН. Сер. Агрономия и животноводство. 2016. № 3.

4. Акаевский А.И., Юдичев Ю.Ф., Селезнев С.Б. Анатомия сельскохозяйственных животных I под ред. С.Б. Селезнева. 5-е изд. М.: Аквариум-Принт, 2005. 640 с.

5. Bureš D, Kotrba R, Barton L, Adamec T. 2010. Antilopa losí-perspektivní druh na talíích œeských strávníkž [Common eland - perspective kind of meat on the plates of Czech consumers] Maso 6:40-43.

6. Прохоров И.П., Никитченко Д.В. Особенности роста мышечной, жировой и костной тканей туш чистопородных и помесных бычков // Вестник РУДН. Сер. Агрономия и животноводство. 2017. № 3.

\section{Literatura}

1. Barton L., Bureš D., Kotrba R., Sales J. 2014. Comparison of meat quality between eland (Taurotragus oryx) and cattle (Bos taurus) raised under similar conditions. Meat Science 96:346-352.

2. Kolbabek $P$. Influence of Common Eland (Taurotragus oryx) Meat Composition on its further Technological Processing. Dissertation thesis. Prague, 2018.

3. Nikitchenko V.E., Nikitchenko D.V., Seregin I.G. i dr. Morfologicheskij sostav tush i razvitie myshc u antilopy kanna // Vestnik RUDN. Ser. Agronomija i zhivotnovodstvo. 2016. № 3.

4. Akaevskij A.I., Judichev Ju.F., Seleznev S.B. Anatomija sel'skohozjajstvennyh zhivotnyh I pod red. S.B. Selezneva. 5-e izd. M.: Akvarium-Print, 2005. $640 \mathrm{~s}$.

5. Bureš D, Kotrba R, Barton L, Adamec T. 2010. Antilopa losí-perspektivní druh na talíích œeských strávníkž [Common eland - perspective kind of meat on the plates of Czech consumers] Maso 6:40-43.

6. Prohorov I.P., Nikitchenko D.V. Osobennosti rosta myshechnoj, zhirovoj i kostnoj tkanej tush chistoporodnyh i pomesnyh bychkov // Vestnik RUDN. Ser. Agronomija i zhivotnovodstvo. 2017. № 3. 